\title{
SODIUM NITROPRUSSIDE: FACTORS WHICH ATTENUATE ITS ACTION. STUDIES WITH THE ISOLATED GRACILIS MUSCLE OF THE DOG
}

\author{
N.A.G. Tremblay, ${ }^{*}$ D.W. Davies, G. Volgyesi, D. Kadar, and D.J. Steward
}

\section{INTRODUCTION}

Sodium Nitroprusside is a ferrous dihydrated nitrosyl pentacyano compound $\mathrm{Na}_{2} \mathrm{Fe}$ (NO) $\mathrm{CN}_{5} \cdot 2 \mathrm{H}_{2} \mathrm{O}$. It was first described in $1849 .{ }^{1}$ Its hypotensive action was shown to be due to peripheral vasodilation by the nitrosyl group. ${ }^{2.3}$ Evidence that this vascular dilatation is caused by interference with the influx of and the intracellular activation of ionized calcium has been presented. ${ }^{4}$ It has been postulated that sodium nitroprusside acts initially at a superficial sulphhydril (-SH) receptor site and, finally, by the oxidation of a second intracellular sulphhydril receptor site. ${ }^{5}$ The clinical pharmacology and toxicity of sodium nitroprusside has been recently reviewed. ${ }^{6.8}$ However, the potential dangers of sodium nitroprusside have become apparent with reports of abnormal responses to the use of sodium nitroprusside. $^{8-14}$

Abnormal responses include tachyphylaxis and resistance to the action of sodium nitroprusside. The use of large or rapid infusions of sodium nitroprusside has the potential for cyanide intoxication. One patient who died ${ }^{10}$ as a result of sodium nitroprusside had lethal levels of cyanide in blood and urine and no measurable thiocyanate in either.

Tachyphylaxis and resistance to the hypotensive action of sodium nitroprusside has been associated with increasing metabolic acidosis, increasing mixed venous oxygen tension, decreasing arterial-mixed venous oxygen content differences ${ }^{14}$ and decreasing cerebral oxygen uptake. ${ }^{9}$ All of these metabolic changes are compatible with cyanide toxicity of cellular cytochrome oxidases and tissue anoxia.

The aetiological factors which determine tachyphylaxis and resistance to the action of sodium nitroprusside have not been elucidated.

It has been suggested that tachyphylaxis may be due to depletion of endogenous thiosulphate ${ }^{14}$ and resistance to an abnormality of cyanide metabolism, possibly due to an hitherto unrecognized abnormal tissue rhodanese. ${ }^{10}$

Why these abnormal responses are associated with an attenuated action of the hypotensive effects of sodium nitroprusside is not known. It has been suggested that accumulation of cyanide ion directly attenuates the effect of sodium

\footnotetext{
'Formerly Research Fellow, Department of Anaesthesia, The Hospital for Sick Children, Toronto, presently Staff Anaesthetist and Assistant Professor, St. Justine's Hospital, University of Montreal.

Reprint requests to: Dr. D.W. Davies, Department of Anaesthesia, The Hospital for Sick Children, 555 University Avenue, Toronto, Ont. M5G 1 X8.
} 
nitroprusside. ${ }^{18}$ Another suggestion has been that acidosis is the cause of the attenuation of the hypotensive effect of sodium nitroprusside.

To test these hypotheses the changes in vascular resistance of the acutely denervated and circulatory isolated gracilis muscle preparation of the $\operatorname{dog}^{15,16}$ were studied using sodium nitroprusside under various conditions.

\section{Methods}

Pure bred beagle dogs, aged 6 to 30 months and weighing 10.0 to $16.8 \mathrm{~kg}$ were anaesthetized with intravenous thiopentone $(30 \mathrm{mg} / \mathrm{kg})$. Anaesthesia was maintained with intravenous thiopentone and the dogs were ventilated with a Harvard pump 607, with 100 per cent oxygen.

The gracilis muscle of the dog was dissected free ${ }^{17}$ and the tendons were ligated. The artery and the vein of the muscle were cannulated with a Clay Adams polyethylene 50 catheter. The venous blood flow was measured by a drop-rate meter calibrated by timed collections of measured volumes of blood. The muscle was maintained at $37^{\circ} \mathrm{C}$ by a warming lamp and dehydration was prevented by covering it with a layer of sterile mineral oil.

The aorta was cannulated with a N.I.H. \#6 catheter and $150 \mathrm{ml}$ of blood was bled into a blood reservoir where it was mixed with $50 \mathrm{ml}$ of heparinized plasmalyte 140 solution (Baxter). The dog received lactated Ringer's solution intravenously at 5 to $10 \mathrm{ml} / \mathrm{kg} / \mathrm{hr}$. Magnetic stirrers kept the blood solution in the reservoir homogenous.

Venous samples were collected under oil for laboratory measurements.

Air at approximately 40 p.s.i. was used to compress high velocity silicone oil (Down Corning 200 fluid, 500 C.S.) in a plexiglass reservoir. The oil flow was controlled by a needle valve and this displaced the canine blood/plasmalyte mixture from the second reservoir. The blood, warmed to $37^{\circ} \mathrm{C}$ by an in-line water jacket, perfused the muscle preparation and was not recirculated. The resistance through the needle valve being so much higher than that of the gracilis vascular resistance (G.V.R.), the perfusion system acted as a constant flow pump.

Appropriately placed two-way and three-way stopcocks along the perfusion line allowed, (1) bleeding from the dog into the blood reservoir, (2) measurement of the arterial perfusion pressure (A.P.P. - Clark Physiological Pressure transducer CM 0109), (3) infusion of drugs intra-arterially, and (4) sampling of arterial blood for laboratory measurements.

The muscle preparation was perfused at a constant rate through the arterial cannula by perfusate from the reservoir. The rate of infusion was similar to what one would anticipate in the normal intact muscle and was of the order of 2 to 2.5 $\mathrm{ml} /$ minute. The experiments were conducted when a steady state of perfusion pressure, blood flow and normal gracilis muscle arterial and venous acid-base and electrolyte status were established.

The gracilis muscle preparation was then perfused for 5 to 10 minutes with (a) sodium nitroprusside at concentrations as indicated in the results, in a physiological and acidic milieu, and (b) sodium nitroprusside and sodium cyanide at concentrations as indicated in the results, in physiological and acidic milieu. 


\section{ISOLATED DENERVATED SEPARATELY PERFUSED}

CANINE M.GRACILIS PREPARATION

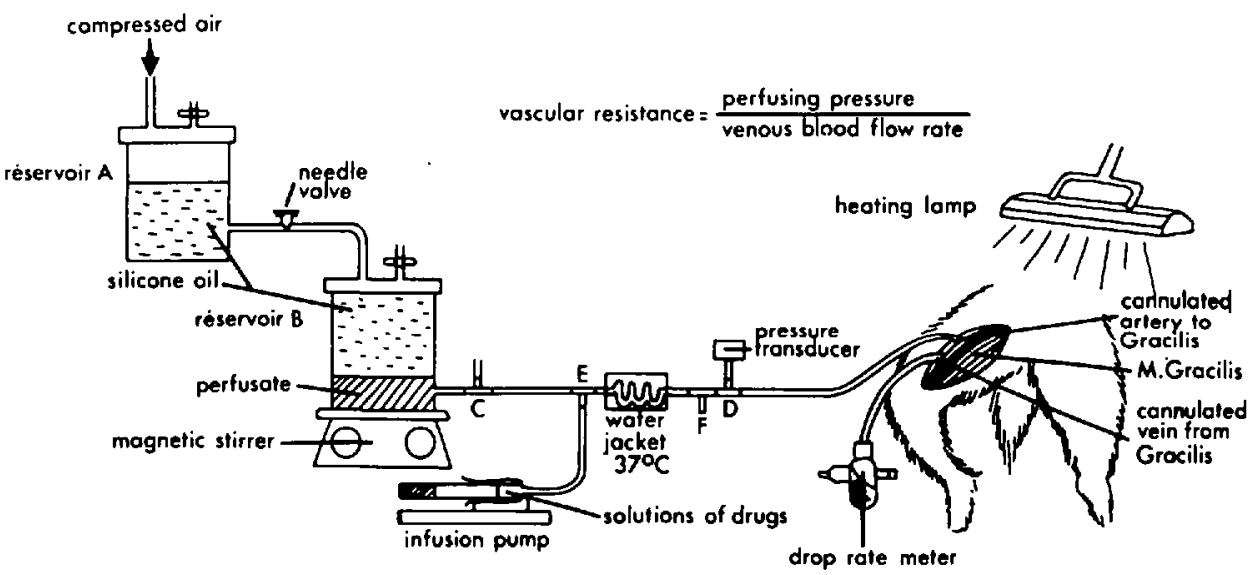

Figure 1. Diagram of experimental arrangement for the studies reported.

Between each infusion of drug a period of perfusion with normal reservoir perfusate was allowed in order to flush the muscle preparation and restore control conditions to the preparation prior to the next drug infusion.

At the end of the experiments the gracilis muscle was removed and weighed. Gracilis vascular resistance (G.V.R.) was calculated, for each minute, from the ratio of arterial perfusion pressure to venous blood flow rate and expressed as $\mathrm{mm} \mathrm{Hg} / \mathrm{ml} / \mathrm{min} / 100 \mathrm{~g}$ of muscle tissue. Figure 1 illustrates the experimental setup.

\section{Drugs}

Sodium nitroprusside was prepared in the pharmacy of The Hospital for Sick Children, Toronto. The stock 1 per cent solution was stored in $10 \mathrm{ml}$ vials at $4^{\circ} \mathrm{C}$ in the dark. A stock solution of 1 per cent sodium cyanide in $0.001 \mathrm{~N}$ sodium hydroxide was stored similarly.

Perfusates of each drug were prepared with 5 per cent dextrose in water immediately prior to each experiment. Solution of $10 \mu \mathrm{g} / \mathrm{ml}$ and $20 \mu \mathrm{g} / \mathrm{ml}$ of sodium nitroprusside and $10 \mu \mathrm{g} / \mathrm{ml}, 20 \mu \mathrm{g} / \mathrm{ml}, 50 \mu \mathrm{g} / \mathrm{ml}, 100 \mu \mathrm{g} / \mathrm{ml}$ and $200 \mu \mathrm{g} / \mathrm{ml}$ of sodium cyanide were used.

Dose rates of sodium nitroprusside and blood cyanide levels attained are indicated in the results.

\section{Measurements, Recordings and Statistics}

The pressures and flows were recorded on a Watanabe Multicorder type MCG-11 and on a Beckman type R.M. Dynograph. Types 9872 and 9803 strain gauge couplers were used.

Blood gases were measured with an I.L. pH/gas analyzer 113. The values of gracilis muscle vascular resistance were obtained from the mean of several minutes of infusion. The percentage change in gracilis vascular resistance was calculated 
TABLE I

Arterial Perfusate

\begin{tabular}{cccr}
\hline \hline $\begin{array}{c}\text { Time } \\
\text { (minutes) }\end{array}$ & $\mathrm{pH}$ & $\mathrm{PO}_{2}$ & $\mathrm{PCO}_{2}$ \\
\hline 0 & $7.37-7.45$ & $140-375$ & $32-38$ \\
180 & $7.35-7.37$ & $60-82$ & $36-46$ \\
\hline
\end{tabular}

TABLE II

Control Muscle Preparation Affluent and Effluent Blood Biochemistry

\begin{tabular}{|c|c|c|c|c|c|c|c|c|c|c|}
\hline & \multicolumn{2}{|c|}{$\mathrm{pH}$} & \multicolumn{2}{|c|}{$\mathrm{PO}_{2}$} & \multicolumn{2}{|c|}{$\mathrm{Na}^{+}$} & \multicolumn{2}{|c|}{$\mathrm{K}^{+}$} & \multicolumn{2}{|c|}{$\mathrm{PCO}_{2}$} \\
\hline & B & $\mathrm{E}$ & B & $\mathrm{E}$ & B & $E$ & B & $\mathrm{E}$ & B & $E$ \\
\hline Affluent & 7.44 & 7.37 & 115 & 72 & 148 & 143 & 3.9 & 4.0 & 32 & 35 \\
\hline Effluent & 7.43 & 7.35 & 35 & 48 & 148 & 141 & 4.0 & 3.9 & 38 & 39 \\
\hline
\end{tabular}

GVR $=\overline{34.3} \mathrm{mmHg} / \mathrm{ml} / \mathrm{min} / 100 \mathrm{~g}$ muscle tissue ( $\pm 10.5 \%$ change).

Blood flow rate $=2.18-2.25 \mathrm{ml} / \mathrm{min} . \mathrm{B}=$ beginning, $\mathrm{E}=$ end.

by comparing the means of the gracilis vascular resistance before and during the administration of drugs.

The data were treated by simple descriptive statistics and were comparcd using the paired $t$ test and $P$ values.

Table I shows the changes in $\mathrm{pH}$ and $\mathrm{Po}_{2}$ of the reservoir blood solution during three hours of perfusion. Our experiments were concluded within three hours and we considered these changes in $\mathrm{pH}$ and $\mathrm{Po}_{2}$ as acceptable.

Table II shows the results of gracilis arterial and venous acid-base and electrolyte status at the beginning and at the end of three hours' perfusion from the reservoir, without infusion of drugs. These results illustrate the integrity of the preparation and the muscle uptake of oxygen. The muscle was acutely denervated by the use of lidocaine.

\section{EXPERIMENTS}

1. The effect of sodium nitroprusside on gracilis vascular resistance at physiological $\mathrm{pH}$

The isolated, acutely denervated gracilis muscle was perfused at physiological $\mathrm{pH}$ with sodium nitroprusside. Table III illustrates the results. There was a significant decrease $(\mathrm{P}<0.005)$ in gracilis vascular resistance (G.V.R.). However, the reduction in vascular resistance was not dose dependent and probably reflects the individual variation of response to sodium nitroprusside as is experienced in clinical practice.

2. The effect of cyanide and sodium nitroprusside on gracilis vascular resistance at physiological $\mathrm{pH}$

Sodium ntiroprusside and then sodium nitroprusside and sodium cyanide were infused at normal $\mathrm{pH}$ into the isolated, acutely denervated gracilis muscle. Table IV illustrates the changes in gracilis vascular resistance. Again sodium nitroprusside significantly reduced the gracilis vascular resistance $(P<0.005)$. The addition of 
TREMBLAY, et al.: FACTORS WHICH ATTENUATE SODIUM NITROPRUSSIDE

TABLE III

ACTION OF NitropRUSSIDE

\begin{tabular}{cc}
\hline \hline & $\begin{array}{c}\text { Gracilis vascular } \\
\text { resistance } \\
\text { Pitroprusside } \\
\mu \mathrm{g} / \mathrm{Kg} / \mathrm{min}\end{array}$ \\
\hline 0.29 & change \\
0.29 & -11.1 \\
0.40 & -21.6 \\
0.40 & -17.6 \\
2.00 & -17.4 \\
3.50 & -18.4 \\
3.50 & -11.7 \\
\hline $\mathrm{P}<0.005$ & -21.6 \\
\hline
\end{tabular}

TABLE IV

Effect of Cyanide On the Action of Nitroprusside

\begin{tabular}{ccc}
\hline \hline & \multicolumn{2}{c}{$\begin{array}{c}\text { Gracilis vascular resistance } \\
\text { Percentage change }\end{array}$} \\
\cline { 2 - 3 } $\begin{array}{c}\text { Nitroprusside } \\
\mu \mathrm{g} / \mathrm{Kg} / \mathrm{min}\end{array}$ & Without CN & With CN $(\mu \mathrm{g} / \mathrm{ml})$ \\
\hline 0.29 & -11.1 & $-5.3(0.25)$ \\
0.29 & -21.6 & $-13.3(0.25)$ \\
0.40 & -17.6 & $-14.0(0.50)$ \\
0.40 & -12.4 & $-10.6(1.50)$ \\
2.00 & -18.4 & $-9.6(1.50)$ \\
\hline $\mathrm{P}<0.005$. & \multicolumn{3}{|}{}
\end{tabular}

TABLE $\mathrm{V}$

Effect of Acidosis on the Action of Nitroprusside

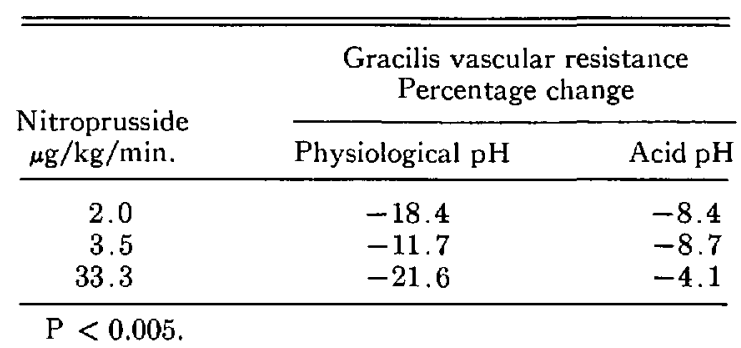

sodium cyanide significantly attenuated the sodium nitroprusside-induced reduction of gracilis vascular resistance $(P<0.005)$. There was still a significant reduction in gracilis vascular resistance $(P<0.05)$ but it was significantly less than prior to the presence of cyanide ion.

3. The effect of sodium nitroprusside on gracilis vascular resistance in an acidotic milieu

The isolated, acutely denervated gracilis muscle was perfused with sodium nitroprusside, using first perfusate with normal $\mathrm{pH}$, and then with an acidotic perfusate by using $0.1 \mathrm{~N}$ hydrochloric acid. Table $\mathrm{V}$ shows the results. The presence 


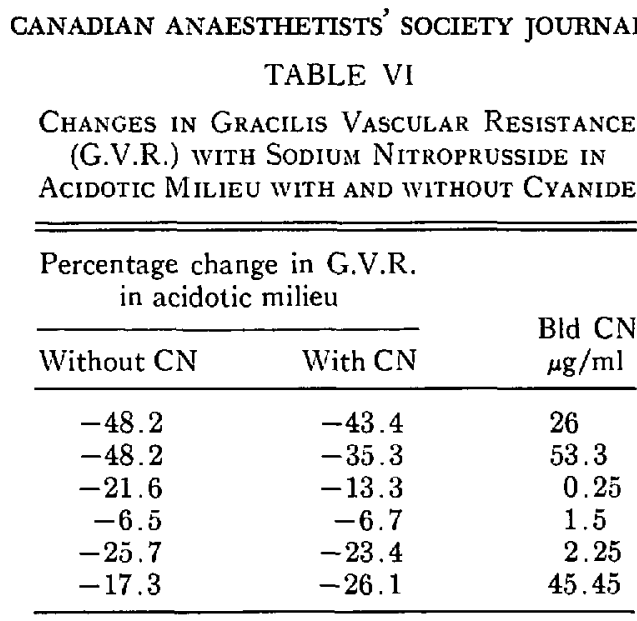

of increased hydrogen in the perfusate significantly $(\mathrm{P}<0.005)$ attenuated the effect of sodium nitroprusside.

4. The effect of sodium nitroprusside on the gracilis vascular resistance in an acidotic milieu, with and without sodium cyanide

Sodium nitroprusside was infused in an acidotic perfusate with and without sodium cyanide into the isolated, acutely denervated gracilis muscle. Table VI shows that under these acidotic conditions no significant change in the reduction of gracilis vascular resistance was produced by the addition of cyanide ions.

\section{ResULTS}

\section{Reservoir}

Table I shows the results of measured laboratory parameters obtained on the perfusate. The $\mathrm{pH}$ and the $\mathrm{Po}_{2}$ tended to fall with time as we limited all experiments to three hours' duration. In all experiments, the measured acid/base relationships and electrolytes of the affluent and effluent blood were within normal limits, except for one experience in which we acidified the perfusate.

\section{The muscle preparation}

Table II shows measurements during a two-hour period of perfusion for one muscle with no infusion of drugs. Little change occurred between simultaneous samplings of affluent and effluent blood, except for the expected change in Po.. The mean vascular resistance was $34.5 \mathrm{~mm} \mathrm{Hg} / \mathrm{ml} / \mathrm{min} / 100 \mathrm{~g}$. The perfusate flow varied between 2.18 and $2.25 \mathrm{ml} / \mathrm{min}$.

Intermittent infusions of 5 per cent glucose in water caused little if any change in affluent and effluent $\mathrm{pH}$ and no significance change in gracilis vascular resistance.

\section{Effect of sodium nitroprusside}

Table III shows that nitroprusside significantly lowered the gracilis muscle vascular resistance $(P<0.005)$. However, this effect was not dose-dependant under our experimental conditions. 
Effect of cyanide on the action of sodium nitroprusside

Table IV shows that nitroprusside at several rates of administration in the same muscle was significantly less effective when cyanide was added to it than when it was administered alone $(\mathrm{P}<0.005)$. However, nitroprusside still produced a significant decrease in vascular resistance.

\section{Effect of acidosis on the action of sodium nitroprusside}

We observed that intermittent and repeated infusions of nitroprusside with and without cyanide, eventually caused the venous blood sample to become acidic ( $\mathrm{pH}<7.35$ ). In two experiments where nitroprusside was administered at uniform dose and rate in the same muscle, but at different $\mathrm{pH}$, we observed that the change in vascular resistance was less in the "acidic" muscle. It appeared that acidosis attenuated the effect of nitroprusside (Table V). Hence, we devised the following experiment. We measured the effect of nitroprusside with a perfusate of normal $\mathrm{pH}$, and determined that the venous $\mathrm{pH}$ was unaffected. Then we acidified the perfusate to $\mathrm{pH} 7.26$ with $0.1 \mathrm{~N} \mathrm{HCl}$, and measured the effect of the same dose and rate of administration of nitroprusside. We found that the nitroprusside was less effective in decreasing the vascular resistance (Table VI).

\section{Discussion}

Our experiments illustrate that sodium nitroprusside significantly reduced the vascular resistance of the isolated gracilis muscle preparation of the dog, and that cyanide and acidosis significantly attenuated this effect of sodium nitroprusside. This muscle preparation (being acutely denervated and isolated from the dog's systemic circulation) would exclude any other explanation for this induced attenuation of the effect of sodium nitroprusside. Amaranath ${ }^{18}$ has suggested that tachyphylaxis to sodium nitroprusside may be due to drug deterioration, too light anaesthesia, CNS ischaemic reflex, hypervolaemia, phaeochromocytoma or reninangiotensin-aldosterone hyperactivity. The very nature of this isolated muscle preparation must patently discount any or all of these explanations.

With regard to the postulate that the final common pathway of all vasodilators is probably through a second deep intra-cellular sulphhydril $(-\mathrm{SH})$ rich receptor ${ }^{5}$ (Figure 2) we speculate that patients who manifest tachyphylaxis or resistance to the hypotensive effect of sodium nitroprusside cannot readily metabolize the free cyanide released from the metabolism of sodium nitroprusside (Figure 3). This free intracellular cyanide is available to interact with the sulphhydril receptors, thus blocking this final common vasodilator receptor. This would also make these receptors unresponsive to vasoconstrictors. The patient who died of cyanide poisoning following sodium nitroprusside was unresponsive to neosynephrine infusion. ${ }^{10}$

It is postulated that strong reducing agents would regenerate the intact sulphhydril groups and would counteract the resistance to sodium nitroprusside. Such a response to the use of thiosulphate in a few patients who have exhibited tachyphylaxis to sodium nitroprusside has been documented. ${ }^{14}$

Cyanide metabolism and toxicity are intra-cellular events. Cyanide intoxication incapacitates cellular cytochrome oxidases and causes cellular hypoxia and 


\section{MECHANISM OF ACTION OF NITROPRUSSIDE: NEEDLEMAN HYPOTHESIS}

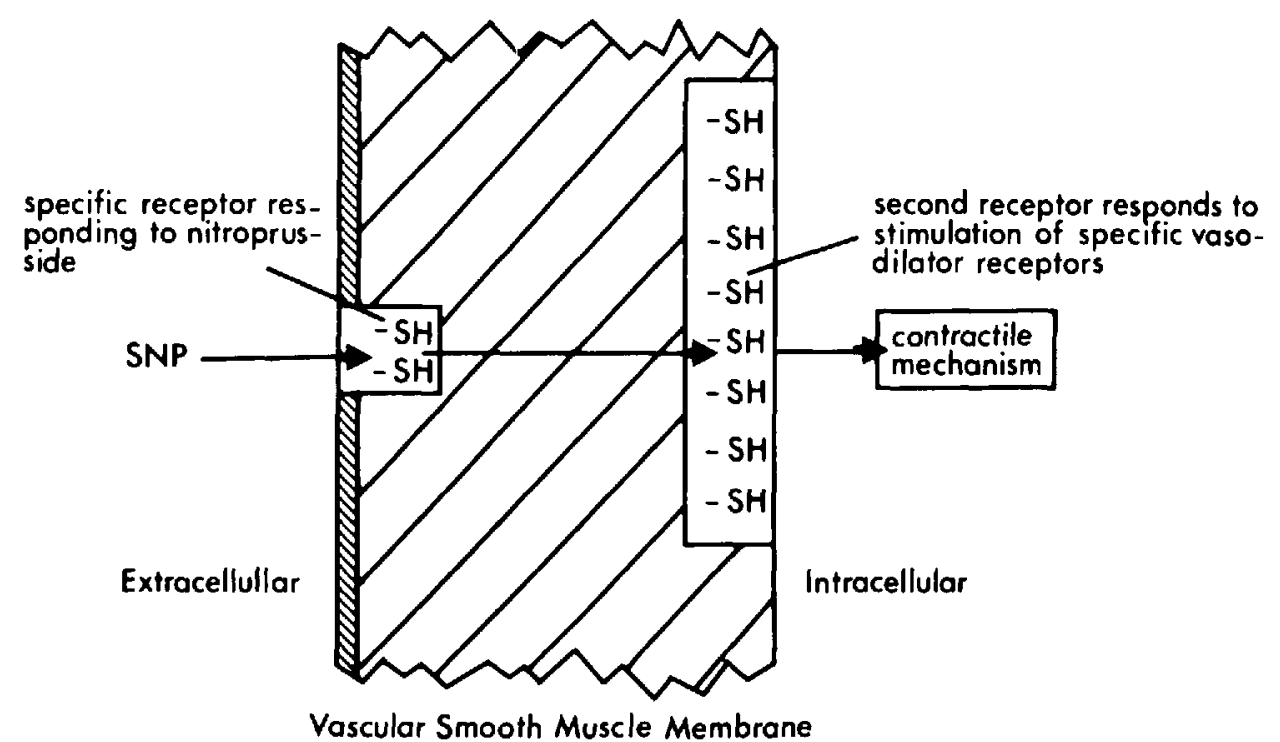

Figure 2. Mechanism of action of nitroprusside. (Modified from Needleman, P., Jarkschik, B., and Johnson, E.M., Jr. Sulfhydryl requirements for relaxation of vascular smooth muscle. Jour. Pharm, Exp. Ther. 187: 324 (1973). The Williams \& Wilkins Co., Publishers, Baltimore, with kind permission of the authors and the publisher.)

BIODEGRADATION OF NITROPRUSSIDE

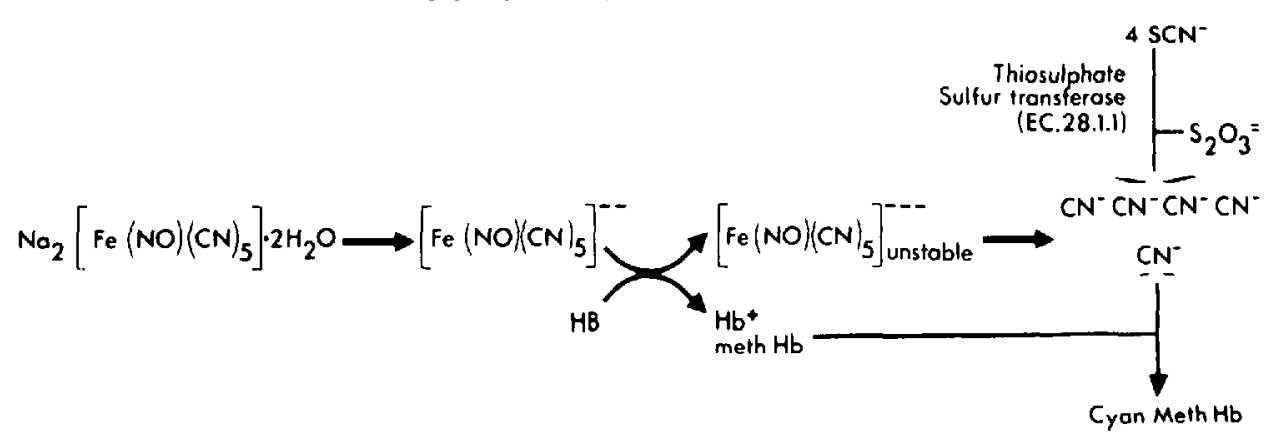

Figure 3. Equation illustrating the biodegradation of nitroprusside.

acidosis. Whether the cyanide ion per se or the intra-cellular acidosis consequent to cyanide toxicity is responsible for the attenuation of the effect of sodium nitroprusside is not perceptible from our experiments.

Resistance to sodium nitroprusside is clinically apparent very early after (within ten minutes ) commencing the infusion of sodium nitroprusside, when arterial acid base status is normal. Tachyphylaxis is more gradual in onset during the infusion of sodium nitroprusside but again when arterial acid base status is normal. Increasing requirements of sodium nitroprusside was attended by an increasing blood cyanide level. This would suggest that in abnormal clinical responses to sodium nitroprusside the attenuation of the effect of sodium nitroprusside is induced by cyanide. However, as arterial metabolic acidosis develops, sodium nitroprusside 
becomes increasingly ineffective, suggesting an additive attenuating effect of cyanide and hydrogen ions.

Vascular intra-cellular hydrogen ion concentration has not been measured. At this cellular level acidosis probably occurs concurrently with increasing intracellular cyanide concentration and significantly precedes arterial acidosis. This being so, we cannot assume by correlating clinical experience with our experiments that the clinical attenuation of the hypotensive effect of sodium nitroprusside is necessarily cyanide initiated. It could possibly be that increasing intra-cellular cyanide has its final attenuating effect on the action of sodium nitroprusside by increasing intra-cellular hydrogen ion concentration.

\section{SUMMARY}

In a laboratory preparation of the isolated, acutely denervated, and separately perfused canine gracilis muscle we have made the following observations:

1. At physiological $\mathrm{pH}$, sodium nitroprusside significantly decreases the vascular resistance;

2. At physiological $\mathrm{pH}$, cyanide significantly attenuates the effect of sodium nitroprusside;

3. In an acidaemic milieu, our data suggest that the effect of sodium nitroprusside may be attenuated.

We speculate that patients who manifest resistance to the hypotensive effect of sodium nitroprusside may not normally eliminate the cyanide that is released from the biodegradation of sodium nitroprusside. They accumulate free cyanide which interferes with the action of sodium nitroprusside at the receptor level, leading to administration of more nitroprusside and setting in motion a positive feedback vicious cycle.

When one is faced with the problem of an abnormal response to sodium nitroprusside in a fit patient, although many factors may be involved, we suggest that the possibility of rising blood cyanide levels and acidosis be given high priority.

\section{RÉSUMÉ}

Nous avons émis l'hypothèse suivante: la cyanure antagonise l'action vasculaire $\mathrm{du}$ nitroprussiate de soude. Pour en faire l'essai, nous nous sommes servis d'une préparation dénervée et isolément perfusée de muscle gracilis du chien. Nous avons fait les observations suivantes :

1. En milieu à $\mathrm{pH}$ physiologique, le nitroprussiate diminue de façon significative la résistance vasculaire;

2. En milieu à $\mathrm{pH}$ physiologique, la cyanure atténue de façon significative l'action du nitroprussiate;

3. En milieu acide, nos données suggèrent que l'action du nitroprussiate est atténuée.

Nous spéculons que les malades qui développent une tachyphylaxie au nitroprussiate ne peuvent éliminer normalement la cyanure qui est libérée à partir de la biodégradation du nitroprussiate. Donc ils accumulent de la cyanure qui inter- 
fère avec l'action du nitroprussiate au niveau des récepteurs et l'on doit de ce fait augmenter la dose de nitroprussiate, ce qui initie un cercle vicieux.

Lorsque le problème de tachyphylaxie au nitroprussiate se manifeste chez un jeune patient, qui est en bon état physique par ailleurs, nous proposons que, parmi toutes les causes possibles, l'augmentation du taux sanguin de cyanure et d'acidose soit considérée en priorité.

\section{REFERENCES}

1. Playfair, L. On the nitroprusside: a new class of salts. London: R.J.E. Tailor (1849).

2. Thienes, C.H. Altered response of smooth muscle to autonomic drugs produced by physical and chemical changes. Arch. Int. Pharmacodyn. 31: 447 (1926).

3. Johrsos, C.C. The action and toxicity of sodium nitroprusside. Arch. Int. Pharmacodyn. Ther. 35: 480 (1929).

4. KreYe, V.A.W., Baron, G.P., Lüth, J.B., et al. Mode of action of sodium nitroprusside on vascular smooth muscle. Naumyn-Schmiederg's Arch. Pharmacol. 288: 381 (1975).

5. Nefdleman, P., Jakschilk, B., \& Johnson, E.M. JR. Sulfhydril requirements for relaxation of vascular smooth muscle. J. Pharmacol. Exper. Ther. 187: 324 (1973).

6. Tinken, J.H. \& Michenfelden, J.D. Sodium nitroprusside: pharmacology, toxicology and therapeutics. Anesthesiol, 45: 340 (1976).

7. TUzec, I.H. Sodium nitroprusside: a review of its clinical effectiveness as a hypotensive agent. J. Clin. Pharmacol. : 494 (197).

8. Greiss, L., Tremblay, N.A.G., \& Davies, D.W. The toxicity of sodium nitroprusside. Can. Anaes. Soc. J. 23: 480(1976).

9. McDowall, D.G., Keaney, N.P., Turner, J.M., Lane, J.R., \& Okuda, Y. The toxicity of sodium nitroprusside. Brit. J. Anaes. 46: 327 (1974).

10. Davies, D.W., Kadar, D., Steward, D.J., \& Munroe, I.R. A sudden death associated with the use of sodium nitroprusside for induction of hypotension during anaesthesia. Can. Anaes. Soc. J. 22: 547 ( 1975 ).

11. JACK, R.D. Toxicity of sodium nitroprusside. Brit. J. Anaes. 46: 952 (1974).

12. Merrifield, A.J. \& Blundell, M.D. Toxicity of sodium nitroprusside. Brit. J. Anaes. 46: $324(1974)$

13. MACRAE, W.R. \& OWEN, M. Severe metabolic acidosis following hypotension induced with sodium nitroprusside. Brit. J. Anaes. 46: 795 (1974).

14. Davies, D.W., Greiss, L., Kadar, D., \& STeward, D.J. Sodium nitroprusside in children: observations of metabolism during normal and abnormal responses. Can. Anaes. Soc. J. 22: 553 (1975).

15. Renkin, E.M. \& Rosell, S. The influence of sympathetic adrenergic vasoconstrictor nerves on transport on diffusible solutes from blood to tissue in skeletal muscle. Acta physiol. Scandinav. 54: 223 (1961).

16. Powell, W.J. JR. \& Skinner, N.S. Effect of the cathetecolamines on the ionic balance and vascular resistance in skeletal muscle. Amer. J. Cardiol. 18: 73 (1966).

17. Martin, E.J., Field, J., \& Hald, V.E. A technique for obtaining and recording isometric contractions of mammalian skeletal muscles in situ. Amer. J. Physiol. 102: 476 (1932).

18. Amaranath, L. \& Kelleriyer, W.F. Tachyphylaxis to sodium nitroprusside. Anesthesiol. 44: $345(1976)$. 